\title{
A Comparative Study of Chemical Fractions Isolated from Agrobacterium tumefaciens and from its Stable L-Form
}

\author{
By R. BELTRÁ, J. RODIGUEZ de LECEA AND C. DE LA ROSA \\ Instituto 'Jaime Ferrán' de Microbiología, \\ del Consejo Superior de Investigaciones Cientificas, \\ Joaquín Costa 32, Madrid-6, Spain
}

(Received 3 December I97I; revised 23 May 1972)

Rubio-Huertos \& Beltrá (I962) were the first to obtain from a phytopathogenic bacterium a stable L-form having pathogenic characteristics similar to the parent. This L-form could induce tumours on different plant species and be recovered from the tumour, showing that it had not reverted in vivo to the parental type. The pathogenicity, chemical composition, etc. of a variety of stable L-forms of micro-organisms pathogenic to man have been studied fairly extensively (e.g. González \& Rubio-Huertos, I959; Nesbitt \& Lennarz, 1965). Less attention has been paid to these forms of plant pathogenic bacteria, although Santaolalla (1963, 1965, 1966) studied Agrobacterium tumefaciens. This communication describes a comparative chemical study of the carbohydrates, amino acids, trichloroacetic acid (TCA)insoluble fraction and nucleic acids from $A$. tumefaciens and from its fixed L-form.

Throughout this work we used strain no. I 3 (from our collection) of Agrobacterium tumefaciens. The fixed L-form was obtained by Rubio-Huertos \& Beltrá (I962) by several successive transfers on glucose nutrient agar containing $4 \%(\mathrm{w} / \mathrm{v})$ glycine and incubation at $26^{\circ} \mathrm{C}$ for 2 to 3 days. Chemicals used throughout this work were of analytical grade from Sigma Chemical Co., St Louis, Missouri, U.S.A., from Probus S.A., Barcelona, Spain, or from Fluka A.G., Buchs S.G., Switzerland.

Bacteria were grown at $26{ }^{\circ} \mathrm{C}$ for 5 days on agar-glucose broth of the following composition $(\mathrm{g} / \mathrm{l})$ : peptone, I0; Difco meat extract, $3 ; \mathrm{NaCl}$, 5; glucose, 20; agar, 20; $\mathrm{pH} 7 \cdot 2$, in Roux bottles. They were suspended in $0.85 \% \mathrm{NaCl}$ solution and then repeatedly centrifuged (3000 $\mathrm{g}, 20 \mathrm{~min}$ ) and washed. The sediment was dried in vacuo over $\mathrm{P}_{2} \mathrm{O}_{5}$ and then weighed. For analysis, the dry bacteria were suspended in distilled water and TCA added to a final concentration of $10 \%(\mathrm{v} / \mathrm{v})$. After storage at $1{ }^{\circ} \mathrm{C}$ overnight, the TCA-insoluble fraction was obtained by centrifugation as above. The precipitate was washed several times with ethanol, ethanol-ether ( $\mathrm{I}: \mathrm{I}, \mathrm{v} / \mathrm{v})$, and finally ether, and amounted to $56 \cdot 05 \mathrm{~g}$ and $4 \mathrm{I} \cdot 40 \mathrm{~g} / \mathrm{I} 00 \mathrm{~g}$ dry bacteria of the normal and L-forms respectively.

The TCA-insoluble fraction was subjected to an acid $\left(6 \mathrm{~N}-\mathrm{HCl}, 100{ }^{\circ} \mathrm{C}, \mathrm{I} 6 \mathrm{~h}\right)$ or alkaline $\left(\mathrm{Ba}(\mathrm{OH})_{2}(4 \%, \mathrm{w} / \mathrm{v}), \mathrm{I} 25^{\circ} \mathrm{C}, \mathrm{I} 8\right.$ to $\left.20 \mathrm{~h}\right)$ hydrolysis and the amino acids identified and estimated by the chromatographic method of Kay, Harris \& Entenman ( I956). The same amino acids were present in the acid hydrolysate of both the normal and the fixed L-form: tryptophan was present in the alkaline hydrolysates of both forms. The concentrations of these amino acids are listed in Table 1 . These results are in accord with the view of Bolton (1962) that the capacity of sphaeroplasts to form their amino acid pool is the same as that of the parent organism. A lower content of amino acids was found for the L-form compared with the normal form (cf. Britten \& McClure, 1962, working with Escherichia coli); this could have been due to damage to the integrity of the normal cell by the action of glycine, permitting a partial loss of the amino acid pool. 
Table I. Amount of amino acids present in the normal and in the stable L-forms of Agrobacterium tumefaciens

Results are expressed as mg amino acid/g trichloroacetic acid-insoluble fraction (columns $\mathrm{A}$ and B) and as $\mathrm{mg}$ amino acid/g of dry wt bacteria (columns $\mathrm{C}$ and D).

(A)

Normal form
$(\mathrm{mg} / \mathrm{g})$

Amino acid

Unknown

Leucine

Phenylalanine

Valine

Tryptophan*

Tyrosine

Alanine

Threonine + glutamic acid

Glycine

Aspartic acid

Arginine

Lysine

Ornithine

Diaminopimelic acid
(B)

Stable L-form

(mg/g)

I.92

$33 \cdot 88$

I I $\cdot 70$

23.00

2.68

I I $\cdot 3$ I

$42 \cdot 70$

$47 \cdot 10$

$31 \cdot 90$

$17 \cdot 53$

$17 \cdot 20$

$24 \cdot 70$

$5 \cdot 17$

$3 \cdot 70$
(C)

Normal form

(mg/g)

Trace

$16 \cdot 90$

$3 \cdot 25$

I $2 \cdot 6 \mathrm{I}$

$4 \cdot 05$

3.10

$2 \mathrm{I} \cdot \mathrm{I} 3$

$24 \cdot 33$

13.52

I I.05

9.02

9.83

0.86

0.97
(D)

Stable L-form

(mg/g)

0.50

$8 \cdot 9 \mathrm{I}$

3.08

6.05

I.03

$2 \cdot 97$

$11 \cdot 20$

I $2 \cdot 40$

$8 \cdot 40$

$4 \cdot 6 \mathrm{I}$

$4 \cdot 50$

6.50

I. 30

0.98

* Estimated after alkaline hydrolysis; other amino acids estimated after acid hydrolysis.

The concentrations of leucine, valine, threonine, glutamic acid, glycine and arginine in the normal form of Agrobacterium tumefaciens were practically double (and three times for aspartic acid) those in the L-form, whereas the concentrations of phenylalanine, tyrosine and lysine were approximately the same. Only ornithine was found in a higher concentration in the L-form than in the normal. Santaolalla (I963) did not find tyrosine, glycine, proline, arginine and ornithine in the 'walls' of the fixed L-form of A. tumefaciens, suggesting that these compounds could be of protoplasmic origin.

Diaminopimelic acid (DPA) was present in the fixed L-form of Agrobacterium tumefaciens at the same concentration (on a dry wt basis) as in the normal form and in a higher concentration, on the basis of the TCA-insoluble fraction.

One or both of two explanations could account for this result. Firstly, mucopeptides or their constituents could be present in the 'walls' of the L-form: amino sugars, alanine and glutamic acid were also detected, and Santaolalla (1963) found a low concentration of DPA in the 'wall' of the L-form. Secondly, the DPA could also be of cytoplasmic origin, as a constituent of nucleotide precursors of mucopeptides (cf. Sharp, I963; Panos, 1964).

These results are similar to those of Fleck (1965) and of Weibull et al. (1967), who found the greatest concentration of DPA in the cytoplasmic fraction of the stable L-form of Proteus mirabilis and of the L strain VI and LD strain of $P$. vulgaris. However, Kandler \& Zehender (1957) considered that DPA was present only in the unstable L-form of $P$. vulgaris, and not in the stable one.

The sugars present in weighed amounts of dried cells of Agrobacterium tumefaciens and of its $\mathrm{L}$-form were identified and estimated after hydrolysis $\left(2 \mathrm{~N}-\mathrm{H}_{2} \mathrm{SO}_{4}, 100{ }^{\circ} \mathrm{C}, 2 \mathrm{~h}\right)$. The hydrolysate after neutralization with $\mathrm{Ba}(\mathrm{OH})_{2}$ and pyridine extraction was chromatographed using butan-I-ol + acetic acid + water ( $40+10+22$, by vol.) by the method of Partridge (I947) with conventional modifications for quantitative determination of the separated sugars. Concentrations (mg/g dry wt) of the sugars found in the normal and L-form of Agrobacterium tumefaciens were respectively: rhamnose, 3.54 and 3.49 ; fucose plus ribose, $3.6 \mathrm{r}$ and 
0.24 ; unknown I ( $\left.R_{F} 0.96\right), \mathrm{I} \cdot 38$ and 0.54 ; xylose, 0.83 and $0 . \mathrm{I} 2$; arabinose, 2.35 and $0 . \mathrm{II}$; glucose plus galactose, I 4.14 and $4 . \mathrm{II}$; unknown II ( $\left.R_{F} 0.90\right), 0.74$ and 0.46 ; sucrose, 0.65 and 0.09 ; raffinose, 0.73 and 0.03 ; maltose, nil and 0.03; unknown III ( $\left.R_{F} 0.19\right), 0.72$ and nil; glucosamine, nil and 0.14 . Maltose and glucosamine were thus present in the fixed $\mathrm{L}$-form but not in the normal form. The concentration of the sugars found in the L-form was generally smaller than in the normal bacterial form: rhamnose was the only methylpentose in approximately the same amount in both forms. These results are generally similar to those of Weibull (1958), who found that the conversion of Proteus vulgaris to its L-form involved a decrease in reducing sugar content.

For nucleic acid estimation, Agrobacterium tumefaciens and its fixed L-form were grown in two sets of shake cultures on the glucose-nutrient broth at $26{ }^{\circ} \mathrm{C}$ for $48 \mathrm{~h}$. From each bacterial form, nucleic acid was isolated by the method of Marmur (I96I) and estimated by the method of Byvoet ( 1966 ). DNA concentrations (mg/g dry wt) were: normal, 4.63 ; L-form, I3.43. Corresponding values for RNA were 13.40 and I6I.9I. Thus, contents of both DNA and RNA were much higher in the stable L-form than in the normal form. These results contrast with those of Panos ( I965), who found, working with other micro-organisms, that the total content of cellular DNA in the stable L-form of a Streptococcus sp. was practically the same as that of the parent and that the concentration of RNA in the L-form was lower than in the normal form.

\section{REFERENCES}

Bolton, E. (1962). Amino acid pool. In Distribution, Formation and Function of Free Amino Acids, p. 766. Edited by J. T. Holden. Elsevier Publishing Company.

Britten, R. J. \& MCCLuRE, F. T. (1962). The mechanism of amino acid pool formation in Escherichia coli. Amino acid pool. In Distribution, Formation and Function of Free Amino Acids, p. 598. Edited by J. T. Holden. Elsevier Publishing Company.

Byvoet, P. (1966). Determination of nucleic acids with concentrated $\mathrm{H}_{2} \mathrm{SO}_{4}$. II. Simultaneous determination of ribo and deoxyribonucleic acid. Analytical Biochemistry 15, 31-39.

FleCK, J. (1965). Etude chimique de la paroi de Proteus PI 8 et de la form L correspondante. Annales de l'Institut Pasteur ro8, 395-398.

Gonzalez, C. \& Rubio-Huertos, M. (I959). Obtención de las formas L de Clostridium tetani inducidas por glicocola. Microbiología Española 12, 339-352.

KANDLER, O. \& ZeHENDER, C. (1957). Über das Vorkommen von $\alpha, \epsilon$-Diaminopimelinsäure bei verschiedenen L-Phasentypen von Proteus vulgaris und bei den pleuropneumonie-ähnlichen Organismen. Zeitschrift fïr Natursforschung 12, 725-728.

Kay, R., Harris, J. \& Entenman, C. (1956). Quantification of the ninhydrin color reaction as applied to paper chromatography. Archives of Biochemistry and Biophysics 63, I4-25.

Marmur, J. (I96I). A procedure for the isolation of deoxyribonucleic acid from micro-organisms. Journal of Molecular Biology 3, 208-2 I 8.

Nesbitt, J. A. \& Lennarz, W. J. (1965). Comparison of lipids and lipopolysaccharide from the bacillary and L-forms of Proteus P18. Journal of Bacteriology 89, 1020-1025.

Panos, C. (1964). Streptococcal L-forms. A biochemical synopsis. Transactions of the New York Academy of Sciences 26, 954-965.

Panos, C. (1965). Cellular physiology during logarithmic growth of a streptococcal L-form. Journal of General Microbiology 39, I3 I-1 38.

PARTRIDGe, S. M. (1947). Application of the paper partition chromatogram to the qualitative analysis of reducing sugars. Nature, London $\mathbf{5} \mathbf{8}, 270$.

Rubio-Huertos, M. \& Beltrá, R. (I962). Fixed pathogenic L-forms of Agrobacterium tumefaciens. Nature, London 195, 4836 , IOI.

Santaolalla, M. ( 1963 ). Obtención y análisis químico de paredes celulares del Agrobacterium tumefaciens y de sus formas L fijas. Microbiología Española 16, 25-39. 
Santaolalla, M. ( I965). Estudio comparativo del componente graso del Agrobacterium tumefaciens y de sus formas L fijas. I. Aislamiento de las distintas fracciones lipídicas. Microbiología Española r8, 3 I-2I.

Santaolalla, M. (I966). Estudio comparativo del componente graso del Agrobacterium tumefaciens y de sus formas L fijas. II. Variaciones según el medio de cultivo y estudio de los fosfolípidos. Microbiologia Española I9, I-Io.

SHARp, J. T. (1963). Amino sugars in L-forms of bacteria and pleuropneumonia-like organism. Journal of Bacteriology 86, 692-701.

WeIBull, C. (1958). Chemical analysis elucidating the structure of bacterial L-forms. Acta pathologica et microbiologica scandinavica 42, 324-332.

Weibull, C., Bickel, W. D., Haskins, W. T., Milner, K. C. \& Ribi, E. (1967). Chemical, biological and structural properties of stable Proteus L-forms and their parent bacteria. Journal of Bacteriology $\mathbf{9 3}$, I $143-1159$. 